\title{
Store Dage
}

\section{Oplevelser ved Genforeningen}

\author{
Af KNUD GJøruP
}

Knud Gjørup (1879-1936) var sognepræst i Køge 1924-36. I den periode skrev han sine erindringer om genforeningsfestlighederne i Sonderjylland i juli 1920, som han deltog i, mens han var sognepræst i Lundforlund øst for Korsør. Manuskriptet ligger $\mathrm{i}$ arkivet ved Køge Kirke. ${ }^{1}$ Gjørup har udgivet andagtsbøger, men ikke flere beretninger - desværre. Hans skildring kan selv nu, 90 år efter begivenhederne, bevæge. Teksten er bearbejdet efter nutidig retskrivning, dog således at den oprindelige tone er bevaret. Noterne er tilføjet af redaktionen.

Minderne om de store dage, da Danmarks konge red over Kongeåen ned i det tabte, men genvundne land, ligger endnu så nær, at tusinder og atter tusinder af danske fra dem henter styrke og håb. Den slægt, som lever nu, vil mindes disse dage som den største nationale glæde, den har oplevet, og vore børn vil fra øjenvidner få en skildring af disse begivenheder og et indtryk af disse dages jubel, som de næppe nogensinde glemmer.

Det kan derfor synes ret overfledigt for den enkelte at nedskrive og offentliggøre sine erindringer fra genforeningsfesten, men den tid kommer dog engang, da også disse store begivenheder vil høre en fjernere fortid til, og til den tid vil det sikkert have sin interesse at eje en skildring af disse jubeldage, således som de blev oplevet af to mænd af folket, to enere i det vældige folketog fra grænsen til Dybbøl. Just gennem sådanne små og store, men ganske private oplevelser, vil man vist mere levende end gennem den officielle beretning kunne få et indtryk af Danmark i fest, og måske tør jeg så også håbe, at nogle af de mange, der selv var med, kan have glæde af at følge os på vor tur og derved opfriske minderne fra deres egen.

2.

I mit barndomshjem på Kronborg blev den 6. februar - den dag, da fader som premierløjtnant blev såret ved Sankelmark - fejret som en af årets største dage, og jeg husker fra en sådan Sankelmarksdag, at 
en oberstløjtnant, der ikke selv havde været med i vor sidste krig, komme på besøg og i samtalens løb ytrede:

»Hvor jeg misunder dig det sår for Danmark! «²

Som dreng forstod jeg kun dårligt disse ord, men jeg har forstået dem bedre siden hen, og gang på gang kom jeg til at tænke på dette udbrud, da 50-års-minderne i 1914 kaldte vort folk til fest for veteranerne, og vi sang til dem:

Den kamp er ej forgæves, hvor æren ej gik tabt. Af dyre fortidsminder vor fremtidshåb er skabt. på eders dåd vi bygger vor kærlighedens ret til endnu vor at kalde den kære, tabte plet.

End springer Volmers løver i Danmarks våbenskjold, end luer hjerter harmfuldt, når moder lider vold. Vi tier vel og bier, - halvhundred år svandt bort, dog visnede ikke håbet: Alt dansk en gang blír vort.

Men næppe var klangen fra disse mindefester forstummet, før gnisten fra Sarajevo fængede i den europæiske krudttønde, og det vældige uvejr, hvis blodige forspil den lille danske hær havde været ene om at udkæmpe i 1864 , brød løs over en stor del af verden. ${ }^{3}$ Krigens rytter red på sin røde hest hen over landene, og "der blev givet ham et stort sværd «. Og mange - også i de lande, som fik lov til at holde sig udenfor - kunne med Vandervelde sige: »I skæret af Belgiens brand lærte jeg, hvad ordet fædreland betyder «. ${ }^{4}$

Danmark var og måtte være neutralt, og dog var vort folk med i krigen, så vist som tusinder af danske fra de tabte egne nu måtte kæmpe for en sag, der ikke var deres egen, og så vist som hundreder af danske sømænd på fredeligt togt blev ofre for krigens voldsfærd. Men under uvejret groede dog det danske håb, og selvom neutralitetens mundkurv dæmpede sangen, nynnede håbet dog i mangfoldige hjerter - med Hostrups lille lærkesang:

Jeg skuer så langt, jeg synger så fro om vælden, der glipper, om duen, der slipper af ørnens klo, 


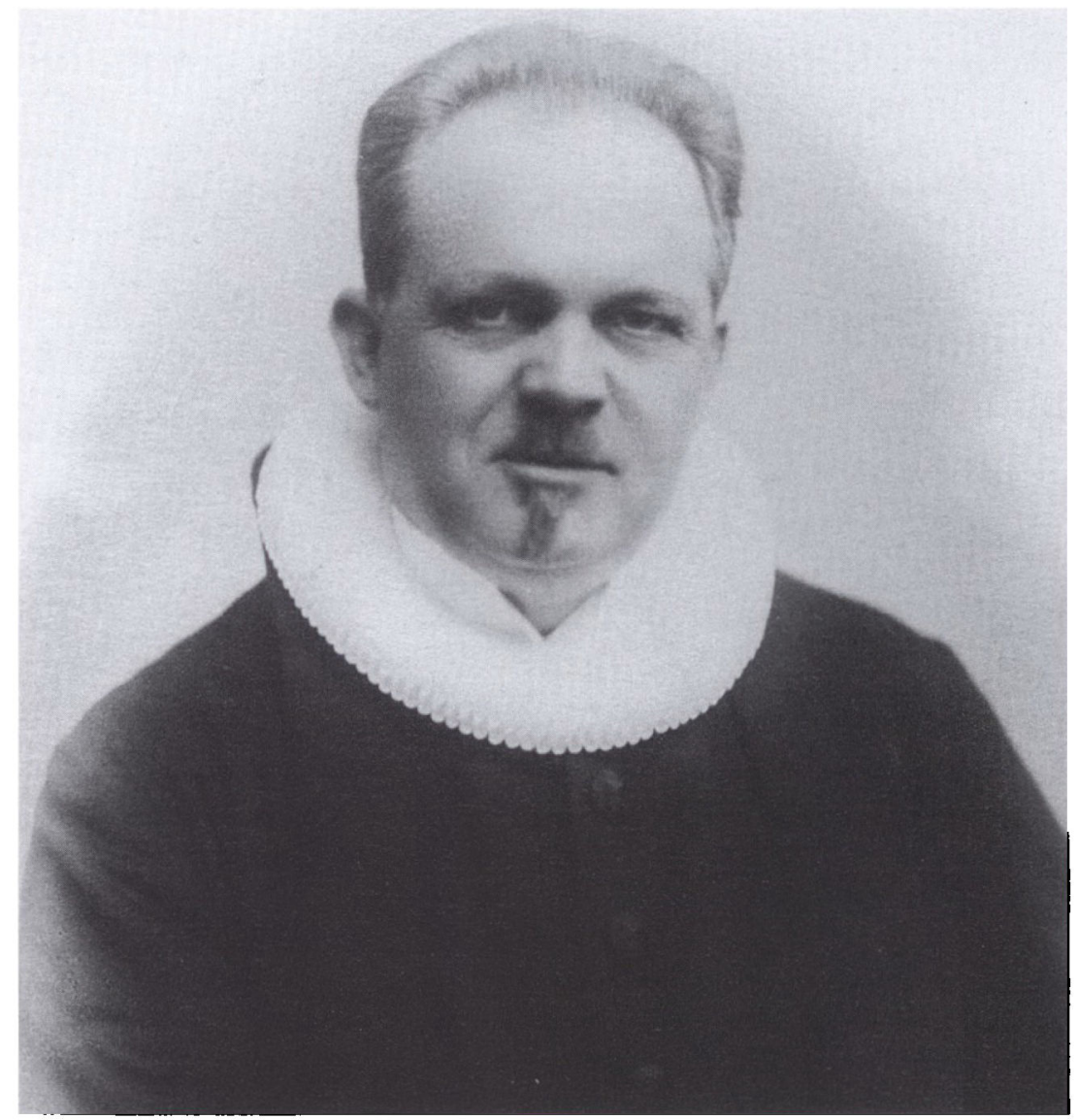

Knud Gjørup (1879-1936). Foto: Køge Byhistoriske Arkiv.
om freden, der kommer
med stordåd og sang,
om sol og skærsommer
i Danevang. ${ }^{5}$

Længe - længe - trak det ud! Men Hostrups lærke var alligevel en profet, og da verdenskrigens kanoner tav, blev der "sol og skærsommer i Danevang«.

Dog! ikke så strålende, som mange havde håbet. 
Det skal siges - ikke for at såre nogen, der tænkte anderledes, men som baggrund for den store glæde, som der her skal fortælles om at det for mig var en bitter sorg, at grænsepælene kun blev rykket op for at plantes på ny gennem gamle danske egne og lukke tusinder af landsmænd ude af fædrelandet. Jeg kunne - og kan - ikke se det anderledes, end at historiens Gud her rakte Danmark en vidunderlig gave, men vort folk havde ikke mod til at modtage mere end det halve. Derfor kom jeg først senere med i glæden over, at Danmark dog blev større - den glæde, der skulle skænke mig to af de største dage, som jeg har oplevet.

3.

Det var den 10. juli 1920 - en dag med sol og skærsommer.

Allerede på Dannebrogsdagen - den 15. juni - var den nye grænse notificeret af den danske og tyske gesandt i Paris, men i dag ville Kong Christian inde i hovedstaden underskrive den traktat med de allierede magter, der overdrog "de sønderjyske landsdele" mellem Kongeå og Kruså til Danmark, og fra hvert eneste kirketårn i landet ringede klokkerne dette budskab ud til de tusind hjem og bar med tonerne folkets tak op til ham, der har "sat folkeslagene deres grænser ${ }^{6}{ }^{6}$

Selv var jeg ikke glad. Endnu var der noget i mig, der græd ved klokkeklangen, og sorgen over det håb, som ikke blev opfyldt, ville ikke give glæden over det vundne rum. - Mit store dannebrogsflag havde jeg svøbt om kirkens alter, ligesom jeg i det hele taget havde søgt at ordne den gudstjeneste, der efter kongens befaling skulle finde sted, så festligt som muligt, og da sognets folk ved middagstid fyldte vor lille, smukke, flag- og blomstersmykkede kirke i Lundforlund, søgte jeg så godt, jeg evnede, at give udtryk også for den glæde, der fyldte så mange sind.

Men selvfølgelig kunne jeg ikke skjule mit eget syn på dagens store begivenhed.

Jeg gik ud fra den ældgamle fortælling om Israels folk, der efter befrielsen fra Ægyptens trældom og efter den lange ørkenvandring omsider kom til det forjættede land, der af Gud var lovet deres fædre, men just som de nu stod ved alle længslers mål, gjorde spejderne dem bange, fordi der var kæmper i landet, og de vovede ikke at tage Guds gave i besiddelse. Derfor blev Herren vred og bød, at ingen af den dalevende slægt skulle se det land, som han havde tilsvoret deres 
fædre, men Herren slog ikke hånden af folket selv, thi - som der står skrevet:

"Eders små børn, ja! dem vil jeg føre derind, og de skal erhverve det land, som I har forsmået."

Og idet jeg nu ud fra denne gamle beretning talte om det nationale håb, der hele mit liv igennem havde lyst for mig, men som jeg i det, der nu var sket, kun delvist kunne se opfyldt - så lykkedes det mig virkeligt at tale mig selv gladere $i$ sind, så at jeg med sandhed kunne sige:

"Vi har opnået en stor glæde, men vore børn skal opleve den største."

Og jeg forlod kirken, grebet af den glade højtidsstemning, der i de følgende dage skulle vokse sig til jubel.

Tanken om at rejse til Sønderjylland og være med til festen dér var dog ikke et øjeblik dukket op i mig, og heller ikke de forskellige festligheder rundt om på egnen ønskede jeg at tage del $i$, men havde bestemt mig til at tilbringe dagen i stilhed.

Lige over for kirken og præstegården i Lundforlund - på den anden side af landevejen - ligger den store proprietærgård Croneshvile, og med dennes ejer, Carl Christian Horn, og hustru, der havde delt håb og skuffelse i det nationale spørgsmål med os, havde jeg aftalt, at de to familier i fællesskab skulle foretage en køretur om eftermiddagen til Kobæk Strand ved Skelskør. Vejret var stille og så varmt, at man følte trang til at smide frakken, men næppe var vi kørt af sted, før der indtraf et pludseligt omslag. En kold sydvestenvind drev tunge skyer op, og ude ved stranden var der så ubehageligt at være, at vi straks vendte om og kørte tilbage til Skelskør Lystskov for at spise til aften dér.

Her sad vi altså - klokken syv aften - bænkede om aftenbordet.

Samtalen drejede sig, som naturligt var, udelukkende om de nationale begivenheder og særlig da om de store forestående festligheder ved grænsen og på Dybbøl. Alle var enige om, at det nok ville blive en prægtig fest.

"Hvis jeg var mand, så tog jeg derover!" - hævdede fru Horn, og de andre damer stemte i med.

"Ja! jeg kunne nok have lyst til at være med på Dybbøl på søndag kunne $d u$ ikke? « - spurgte Horn, og ved dette spørgsmål vågnede lige så voldsomt som brat lysten hos mig til at være med derover, men vanskeligheden ved at få de to gudstjenester om søndagen aflyst gjorde 


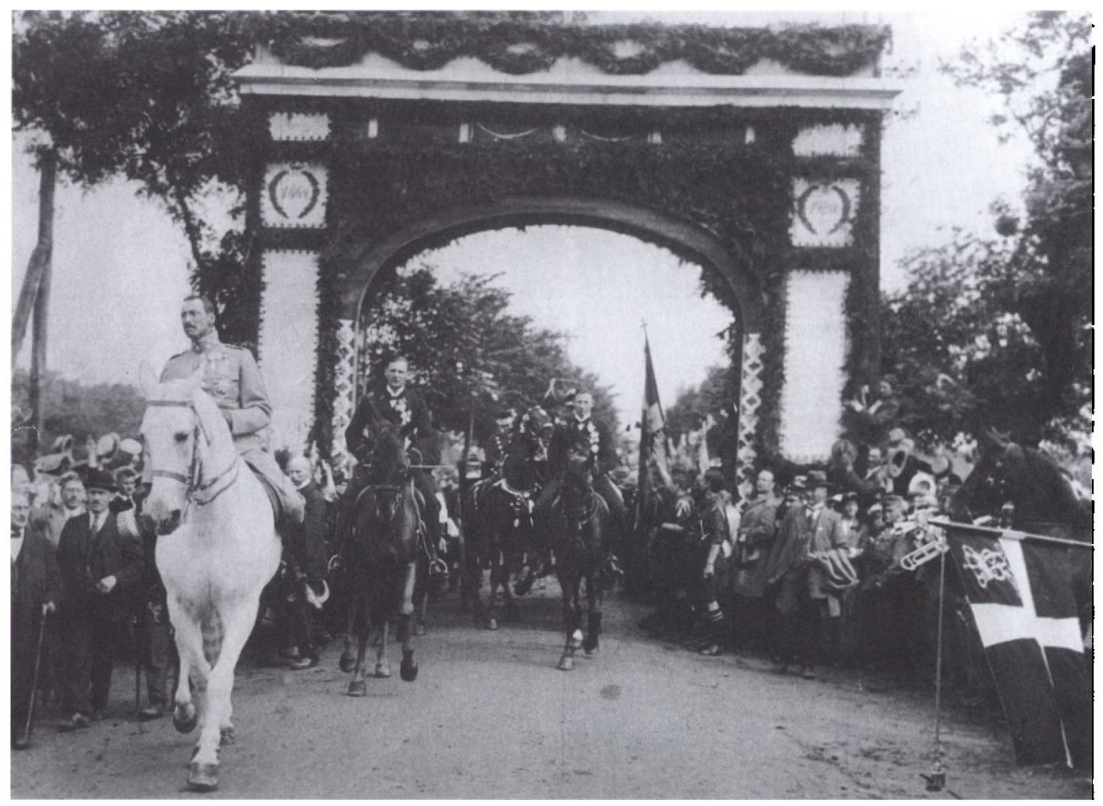

Christian X rider over grænsen ved Frederikshøj den 10. juli 1920 på den hvide hest, som spaet af Jomfru Fanny fra Aabenraa. Hun forudså kort for $\sin$ død $i$ 1881: "... Det bliver ikke Christian IX, som kommer herned som dansk konge. Kongen, som kommer hertil, er en mand $i$ sin bedste alder, hverken gammel eller ung. Han kommer ridende på en hvid hest. Bonderne vil pynte deres heste med bonderoser, og der vil være sort af mennesker for at tage imod ham, men jeg ser ikke et eneste bekendt ansigt ...«. Foto: Museum Sonderjylland - ISL-Lokalhistorie.

mig en del betænkelig, selvom min kone nok mente, at hun kunne sørge for det om lørdagen ved skolernes og landspostens hjælp.

»Skulle vi derover, så ville jeg helst være med ved grænsen«, svarede jeg, stadig lidt tøvende.

"Det kan vist nås endnu! - med færgen 9.18! - skal vi?«, spurgte Horn æggende, og så lod jeg alle betænkeligheder fare.

"Jeg er klar!«

Hele selskabet sprang op for med rasende travlhed at hiælpe os til at nå frem i rette tid. På kun syv kvarter skulle alt pakkes ned i vognen, og damerne køres de ti kilometer til Lundforlund, hvorfra vi så måtte cykle de 16 kilometer til Korsør. Udsigten til at nå det var kun ringe.

Da vi i skarpt trav var nået til hjemmet, og Horn og jeg - forsynede 
blot med penge og tobak - sprang på cyklerne, var der kun 38 minutter til færgens afgangstid. Det småregnede, så at vi desværre måtte have overfrakker på, særlig da vinden var os imod, og hvad der for mig var det værste: min egen cykel havde vist sig punkteret, så at jeg $i$ hast måtte låne en fremmed cykel, der var meget tung at trække, og hvis pedaler jeg kun lige kunne nå med tåspidsen. Gentagne gange var jeg da også ved at opgive det hele, så at kun min djærve rejsekammerats energi fik ægget mig til fornyede anstrengelser, men kl. 9.18, da færgen skulle gå, var vi endnu fire kilometer fra Korsør havn. Her byttede vi imidlertid cyklen, og nu gik det bedre fremad. Da jeg ankom til stationen, havde Horn allerede taget billetter og greb nu min cykel, som han kastede ind over Skranken til bagagerummet.

"Jeg er Horn!« - kommer på mandag!« - råbte han, og uden at bekymre os om vores køretøjers videre skæbne ilede vi ud, hvor færgen allerede - 14 minutter forsinket - var sat i gang, men uden betænkning løb vi ud på den optrukne broklappe og sprang derfra over på færgen, hvor jeg segnede om på dækket, drivvåd af regnen udefra og sveden indefra.

"Vi kom med, du!« - råbte Horn helt sejrsstolt og ikke særlig medtaget af turen.

„Omen accipio!« - tænkte jeg ved mig selv, og i virkeligheden blev denne begyndelse som et godt varsel for hele denne tur: uhyre anstrengende, men altid kronet af et ganske mærkeligt held. ${ }^{7}$

4.

Der er vist intet, der bedre knytter mennesker sammen end dette: at en stor og glad forventning drager dem mod et fælles mål, og det kendtes på tusinder, der fyldte færgens kahyt og dæk, at noget ganske enestående var i gære. Man havde - idet man fulgte strømmen vestpå, fra færge til tog og fra tog til færge - en egen anelsesfuld fornemmelse af, at vor strøm kun var en af de mange strømme, der fra alle egne af Danmark ville mødes den kommende morgen i det vældige folketog ved grænsen, og en sådan stemning kan give kræfter, der gør, at selv det besværlige synes let.

At finde en hvileplads om bord var ganske umuligt, både på færgen og senere $i$ toget over Fyn måtte vi stå op som sild $i$ en tønde, og først $i$ toget fra Fredericia fik vi lov til at sidde ned, men alligevel står denne rejse slet ikke for min erindring som trættende og besværlig, 
og da vi klokken halv tre om natten ankom til Kolding, følte vi os begge så friske som nogensinde.

Sommerdagen var ved at gry, men regnen sivede ned, og himlen, som var ganske grå, gav slet ingen løfter om sol over den kommende fest. I Kolding sov befolkningen endnu den glade forventnings søvn, men klokken otte ville kongen på "Danebrog « sejle ind til byen, og at borgerne ville berede ham en festlig modtagelse, forstod vi, da vi gik gennem byens gader, hvor flere æresporte var rejst, og husenes facader smykkede med blomster og flag.

På Sydbanegården fortalte et opslag os, at det forste tog til Taps ville afgå lidt før klokken fem, og der var altså endnu et par timer at vente for den snes mennesker, der var kommen derud sammen med os.

"Havde man bare en kop kaffe!«, sukkede jeg.

"Der ligger en café derhenne«, pegede en.

»Den er vist ikke åben endnu!«, erklærede andre.

"Vi dundrer dem op! - påstod Horn med sædvanlig raskhed.

Og som sagt, så gjort! Hele flokken vandrede hen til den lille café og begyndte så ihærdigt at bearbejde døren med knytnæver, at der virkelig efter blot et par minutters forløb viste sig en svær mandfolkeskikkelse i døren, kun iført skjorte og bukser og med et ansigt, der var alt andet end velvilligt.

»Vi åbner først klokken seks«, - vrissede han.

Men Horn, som var flokkens anfører, lod sig ikke vise af.

»De må da være glad, mand, ved at få en sådan invasion«, - hævdede han. "Vi er tyve mand, som skal ned til grænsen og gerne skulle have kaffe, før toget går. De må skam være en sløj vært, hvis de ikke tager denne forretning med.«

»Vi kan ikke lave kaffe på et minut«, - brummede værten med et ihærdigt forsøg på at få morgengnavheden bort. »Jeg skal se, om jeg kan få kvinderne op.«

»Men kaffen skal være god - og varm!« - brølede Horn efter ham.

Og det skal siges til caféens ære, at dens kvinder i en prisværdig fart kom op og fik lavet os en god og varm kop kaffe, og da vi havde drukket denne til et stykke franskbrød og fik morgencigaren tændt, følte vi os i stand til at møde alle kommende strabadser.

Fire mænd - om jeg husker ret: fra Langeland, Thisted, Køge og Lolland - havde særlig sluttet sig til os, og vi seks bestemte at holde sammen på turen, men ak! endnu før vi nåede grænsen, blev de borte fra os 


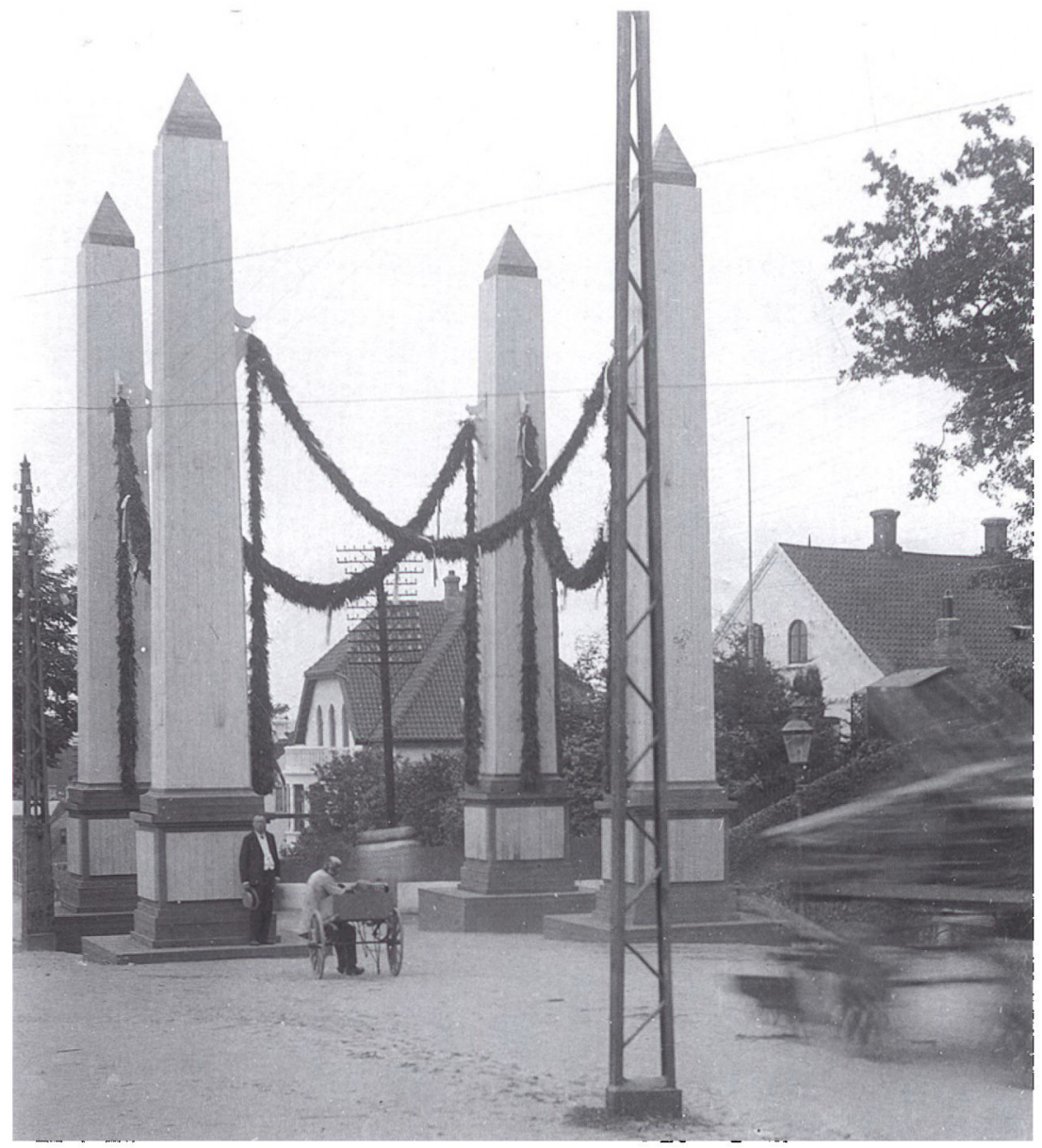

Også andre steder som f.eks. her $i$ Kolding, hoor Gjørup gjorde ophold, inden turen gik videre sydpå, var der rejst æresporte for kong Christian X. Foto: Museum Sonderjylland - ISL-Lokalhistorie.

i trængslen, og vi så dem ikke siden. Dog fulgtes vi ad i morgentoget, der ikke var særlig overfyldt, og klokken kvart over fem ankom vi til Taps, hvor vi modtog det første varsel om, hvor vældig dagen ville blive.

Straks da vi kom ud af toget, kunne vi overse en betydelig strækning af den brede chaussé, der fører fra Kolding ned i Sonderjylland, og den- 
ne vej, der ellers på den tid af døgnet ligger tom og nattestille, var nu opfyldt af et festligt bølgende folketog, så langt som øjet kunne nå. Flagsmykkede automobiler og vogne rullede langsomt af sted mellem en hærskare af cykler og fodgængere, der mange steder, hvor vejen ikke gav plads nok, bredte sig ud over markerne, og alle bevægede sig mod syd, ned mod den grænse, der ikke længere var en grænse. Hist og her lød kendte danske sange, morgenglade hilsener veksledes mellem mennesker, der aldrig havde set hinanden før, og hverken regnen, der stadig faldt så småt, eller vejens frygtelige pløre evnede at gøre skade i den glade stemning, der drev skarerne mod syd.

Et sådant folketog klokken fem om morgenen! - det var et syn, der måtte gribe et dansk sind, og drevne af en forventning, der nærmede sig til stille begejstring, sluttede vi os til toget for at vandre de to kilometer ned til grænsen ved Frederikshøj forbi den festplads, hvor kongen klokken ni skulle bestige den hvide hingst. Kun skridt for skridt gik det fremad, alt for langsomt for vor utålmodige længsel, hvorfor vi gang på gang veg ud på markerne for at komme hurtigere frem, og endelig - klokken kvart i seks - nåede vi vort mål: den grænse, der nu kun var et ondt minde.

5.

To milepæle stod ved vejen, kun en alen fra hinanden; de meddelte kilometerafstanden - den ene "fra Kolding «, den anden »von Altona«, og mellem de to lå grænsepælen væltet.

Forunderlige tanker gik igennem vort sind, da vi stod ved dette sindbillede på det store, som var vundet. Hvor ofte havde jeg ikke stirret med længsel over denne grænse ned mod »det elskede, omstridte land « og søgt min trøst i det kendte ord:

"Troen kan flytte bjerge - så kan den vel også flytte pæle nogle mile mod syd!

Og nu var det sket. Lige ved den væltede grænsepæl hævede den skønne triumfbue sig over vejen med et "Velkommen til Sønderjylland", og - som alle andre - blottede vi uvilkårligt hovederne og gik med hjerter, der bankede af glad bevægelse, ind under buen - ind i det genvundne land. Men man må have oplevet dette selv - med et dansk hjerte - for rigtigt at forstå, hvad disse skridt betød af glæde. Der var klang af sejr og jubel i de tusinde fodtrin, der lød hen under den stolte triumfbue hin sommermorgen, da det store danske folketog drog ind 
i Sønderjylland til fest. Hvert eneste fodslag forkyndte jo, at grænsen ved Kongeåen var slettet.

Kun et kort stykke - vel ca. 100 meter - syd for triumfbuen havde man rejst en lille, beskeden talerstol af gran ved vejens vestlige side, og da vi anede, at det var dér, at kongen skulle modtage den første velkomsthilsen i Sonderjylland, vendte vi efter en tur ned til det gamle toldsted tilbage til denne plads og plantede os ved vejen lige over for talerstolen.

"Nu viger vi kun for bajonetterne", sagde jeg - uden at ane, at dette virkeligt skulle blive til sandhed.

»Det er hørt! - svarede Horn.

Og når jeg nu tænker på, at vi dér - efter en anstrengende rejse og en gennemvåget nat -stod plantede på den samme plet $i$ vejens lerede ælte $i$ tre en halv time, så undrer jeg mig over, hvor disse timer vel blev af - for vist er det, at tiden ikke på nogen måde faldt os lang.

Regnen var hørt op, men himlen var stadig grå, og skydækket lå tungt hen over den skønne egn, der bugtede sig i bakke og dal med grønne skove og frodige marker - så dansk, så velsignet dansk! Men alle vegne var der flag og festglade mennesker, og folketoget gennem triumfbuen blev ustandselig ved, så at der var nok at tale med og mere end nok at se på - automobiler og vogne rullede frem i en så uafbrudt række, at det ikke ville være let at slippe over vejen, og en af de sidste, der kom, før trafikken klokken halv ni blev standset, var en rutebil, der klokken ti den foregående aften var kørt ud fra Mariager; den var stuvende fuld af mennesker, og ovenpå taget lå seks karle svøbte $i$ tæpper og drivvåde efter nattens regn, men med et humør, der straks hilste os med hurraråb, da vi vinkede til dem. - En mand ved siden af os havde en liste over bogstaverne på automobilernes skilte, hvoraf man kunne se, fra hvilke amter de var, og en tid underholdt vi os med at bestemme de forbikørende bilers hjemsted, hvorved vi stødte på alle bogstaver undtagen tre og derved fik konstateret, at med undtagelse af Bornholm var alle amter i Danmark præsenterede pr. bil ved grænsefesten.

"Bornholm mangler!« forkyndte Horn, hvis stemme gerne kunne høres viden om.

"Men kun pr. bil!« - svarede en syngende bornholmsk stemme et sted ude i mængden.

Men også adskilligt andet var der, som holdt opmærksomheden 


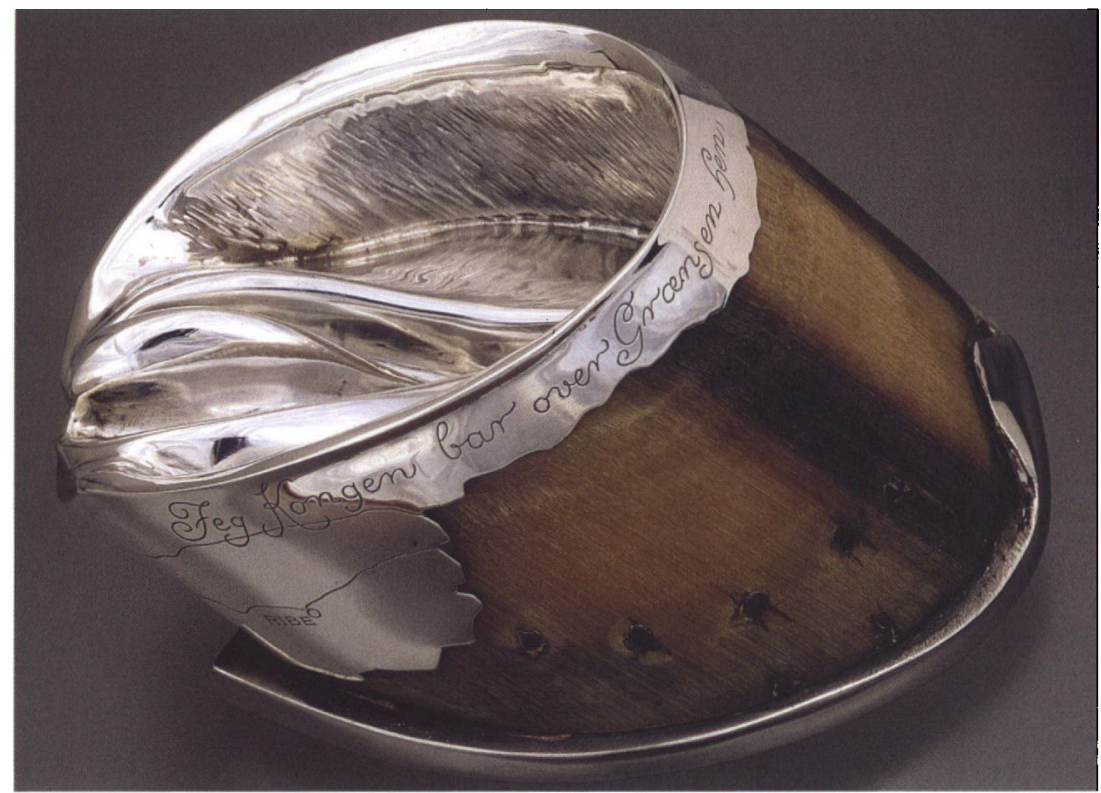

For at hædre hesten, Malgré Tout, der bar kongen over grænsen den 10. juli 1920, blev der aldrig siden redet på den. I 1921 blev Malgré Tout aflivet og begravet $i$ en mindehøj på Visborggårds jorder. En af hestens hove blev forsalvet og skænket kongen $i$ 1923. På hoven er der ligesom på Malgré Touts gravsten indgraveret: »Jeg Kongen bar over Grænsen hen". Kongen brugte gaven som askebæger $i$ sit arbejdswærelse pa Amalienborg. Foto: Kit Weiss, De Danske Kongers Kronologiske Samling, Amalienborgmuseet, Christian VIII's Palæ.

fangen. Skaren på begge sider af grænsen voksede med hvert minut og dannede langs med vejen og langt ud over markerne en uigennemtrængelig menneskemasse: folk af alle stænder og fra alle egne af vort land, mænd og kvinder, unge og gamle - en mægtig, forventningsfuld hær! - I træerne ved vejkanten hang på alle grene, der var tykke nok til at bære, unge mænd og kvinder, hvis ikke altid vellykkede klatreforsøg vakte megen munterhed, men i øvrigt var der velvillige hjælpere nok, og en snedig dreng havde lavet sig en stige af grene, som han for en skilling lejede ud til enhver, der ønskede at betragte den festlige scene »i fugleperspektiv«.

Jo nærmere vi kom til tiden for kongens ankomst, desto mere broget blev det billede, der udfoldede sig for øjet. Sønderjyske ringridere paraderede til hest og med lange lanser ude på marken - hundreder 
af sønderjyske piger i hvide kjoler med rødt skærf dannede allé ved vejen for at strø blomster for kongen, hvor han red frem, og nu, da vejen blev holdt ryddelig af det ypperlige "grønne politi«, der forstod at gøre sin pligt med hensynsfuldhed og dansk humør, indfandt de kendte mænd, der skulle spille en rolle ved festen, sig efterhånden på pladsen, bl.a. amtmand Vedel $^{8}$ og Kloppenborg-Skrumsager. ${ }^{9}$ Og endelig klokken halv ni marcherede 1. sønderjyske bataljons 2. kompagni, som skulle danne æresvagten for kongen, frem og tog opstilling lige over for talerstolen, og nu måtte vi virkelig vige for bajonetterne. Til trods for harmfyldte protester mod, at vi, som havde ventet tålmodigt i hen ved fire timer, nu skulle berøves vor plads i første parket, var der selvfølgelig intet at stille op - men ulykken blev da heller ikke stor. Både kaptajn Bülow, som forte vagten, og som jeg kendte fra mit hjem, og sergent Madsen, der var min legekammerat fra drengeårene på Kronborg, optrådte med så stor en forekommenhed, som den militære pligt ville tillade dem, og selve chefen, oberst Moltke, der holdt til hest ved flanken af kompagniet, trøstede venligt folk med, at han, så snart kongen kom, ville ride frem, og - "så kan De komme til igen «.

Endelig tog en blid form for bestikkelse al vor bekymring bort. Blandt soldaterne, som for det meste stod »rør«, og som vi derfor snart kom i livlig samtale med, var der nemlig en, der ytrede: »Havde man bare noget at ryge på! « og da jeg hjemme havde stoppet frakkelommerne fulde af cigarer, fik jeg hurtigt en halv snes stykker frem og fordelte dem mellem de nærmeste af vagten, der samtidig fik tildelt hver sit "ammunitionsrum " mellem Horns eller mine udspilede fingre, for at de $\mathrm{i}$ hast kunne anbringe cigaren dér, når en eller anden, for hvem der skulle gøres honnør, nærmede sig. Denne gavmildhed, som vi ikke fik grund til at fortryde, efterdi hele restoplaget af mine cigarer en time senere var knust til snustobak i den store trængsel, indbragte os et velvilligt løfte om »et snævert pas", hvorigennem vi kunne slippe frem, når kongen kom - for $d a$ ville sikkert ingen bekymre sig hverken om æresvagten eller om os.

Imidlertid nærmede klokken sig til ni, og spændingen i de store skarer var i kendelig stigning. Og just nu - fem minutter for klokken $\mathrm{ni}$, da den fjerne brusen af hurraråb forkyndte, at kongen var undervejs - just nu brød solen frem i al sin glans og fejede for resten af de to festdage alle skyer bort fra himlen.

Det store, historiske øjeblik var nær. 
6.

Mange varme hjerters tanker og mangfoldige flittige hænder havde virket sammen for at berede vor konge en festlig vej ved hans indtog i længslernes land, og gang på gang i disse dage måtte vi beundre den kloge indsigt og skønhedssans, hvormed alt var ordnet og lagt til rette. Intet offer var sparet, og intet arbejde skyet for at give denne Danmarks enestående fest en ramme, der $i$ enhver henseende var dens storhed og glæde værdig. På de få kilometer fra grænsen ned til Haderslev var ikke mindre end 18 æresporte rejst, og hele vejen ikke mindst da byerne undervejs - var som en eneste festsal, over hvis flag og blomster sommersolen lyste om kap med smilet - og tårerne $-\mathrm{i}$ alle øjne.

Og alligevel! hvor pragtfuld denne ramme om festen end var, så betød den dog ikke mere, end en ramme bør betyde, og af alle arrangementer var de, der fødtes ud af den stærke stemning selv, som regel dem, der greb sindet dybest. Den store glæde skabte - $\mathrm{i}$ folkets som $\mathrm{i}$ kongens færd - adskillige improvisationer, som intet officielt program havde kunnet udforme, og allerede her ved grænsen gav dette sig til kende på den skønneste måde. Vor konges ridt ind i Sønderjylland fik en indledning, der ikke godt kunne tænkes smukkere - et gribende præludium, der var dette enestående øjeblik i vort folks historie værdigt.

På en lille festplads ved vejen nord for grænsen, hvor den hvide hest ventede på sin rytter, og hvorfra den kongelige kortege skulle udgå, blev kongen modtaget af sognerådet $i$ Taps, og i de tyve minutter, som gik hen dermed, nåede forventningen $i$ de store skarer en sådan spænding, at den krævede udløsning. Alle samtaler var gået $\mathrm{i}$ stå, fordi alle sind kun var opfyldte af dette ene: øjeblikket - det, som det danske håb i mere end et halvt århundrede havde ventet på, var kommet.

Da var det, at skarerne nord for grænsen begyndte at synge:

Slesvig, vort elskede, omstridte land!

Du, som så hårdt bliver tynget af åget,

ej fra dit moderland vristes du kan,

thi du er bunden ved hjertet og sproget.

Brødre, hold ud, holder tappert ud!

stol på vor sag, men dog først på Gud!

Slesvig, Slesvig, omstridte land. 
Men da de nu tav, fortsatte skarerne syd for grænsen med det næste vers:

End er vor trøst på den jernhårde vej, dejlige håb, som dog aldrig kan slukkes: det, at vort barnebånd bryder man ej, det, at ej moderens hjerte kan lukkes, dette, at engang i salig lyst barnet făr udgrædt ved moders bryst. Slesvig, Slesvig, Danemarks Land.

Og så tog de fat igen nord for grænsen, medens vi tav:

Omstridte er vi, dog enige i, Dankonning vi som vor fyrste vil kalde. Elskede drot, med hver dansk stå os bi! Alle med dig vil vi stå eller falde. Hvad der end sker, vi vil holde stand, aldrig vi svigte vor drot og land.

Slesvig, Slesvig, elskede navn.

Svagere i selve sangen, men brusende i omkvædet lød Thaulows kendte sang - som indledning til en tusindstemmig vekselsang over grænsen - en sang, som fyldte de forventningsfulde minutter og i den lyse sommermorgen lød vidunderlig smuk. ${ }^{10}$ - Den sidste sang var »Kongernes konge, « men næppe havde vi syd for grænsen sunget det sidste vers:

Herrernes herre! Mægtig og stor, nådig du høre vort bedende kor!

Herre, du ene

kan sejren os forlene,

værn om vort herlige og ældgamle nord!

- før brusende hurraråb med klang af en ganske ny begejstring forkyndte, at kongen havde besteget den hvide hest og red mod grænsen.

Og så skete det - ! 


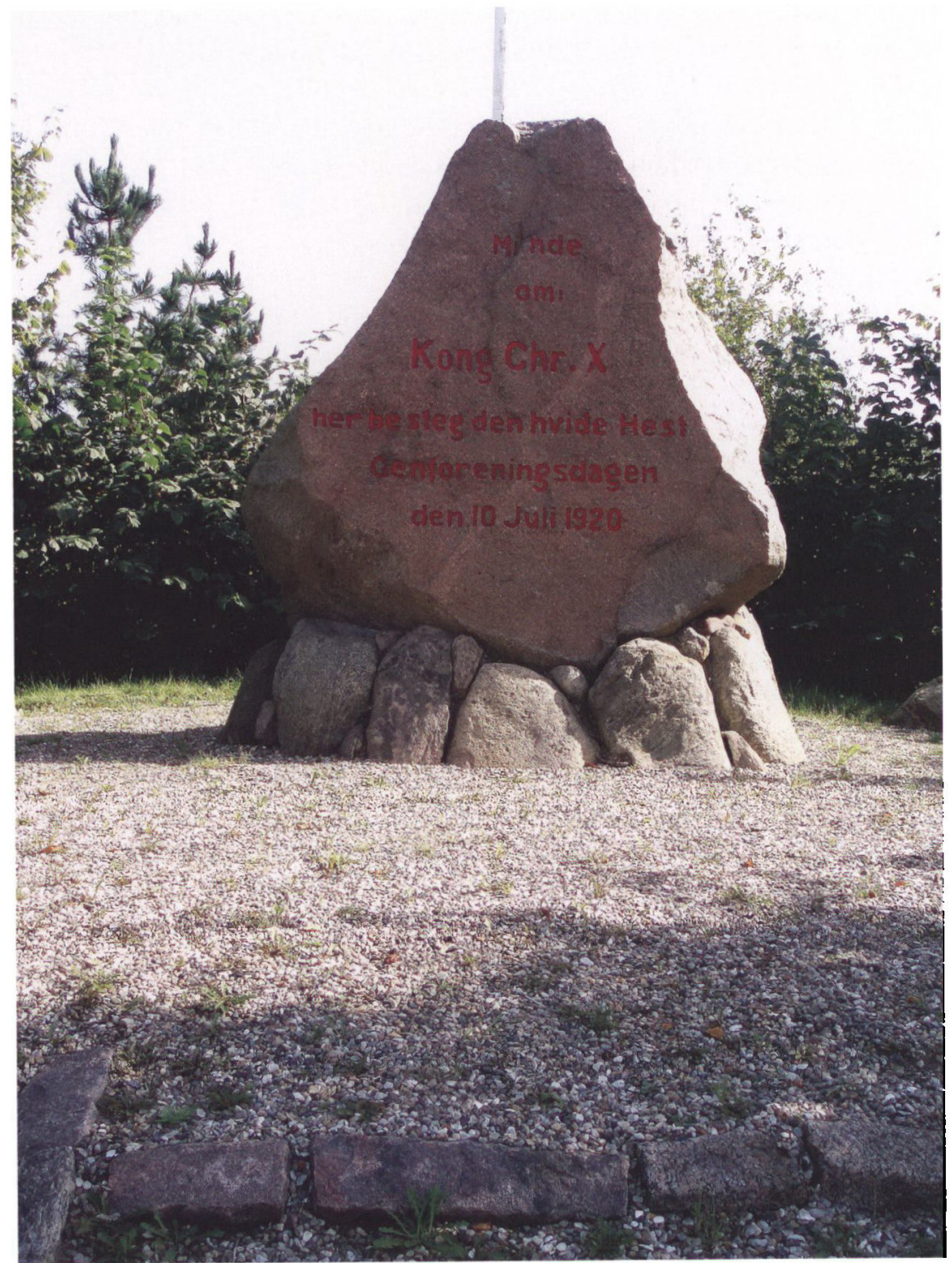

Mindesten på det sted $i$ den sydlige del af Taps, hoor Christian X steg op på den hoide hest, inden han red over grænsen. Mindestenen blev rejst af Vejle Amt og de otte sogne og afsloret den 20. oktober 1921 under overvarelse af kongen. Prizat foto. 
De danskes drøm blev virkelighed, og det blev af nåde forundt os at se det syn, som ingen, der var med, vil glemme.

Kong Christian den Tiende red over Kongeåen.

Red ind i det gamle danske land, som ingen dansk konge havde gæstet, siden Christian IX i 1864 forlod Dybbøl Skanser.

Jeg havde ofte hørt sige, at den stærkeste stemning er tavs, men jeg havde aldrig oplevet dette før.

$\mathrm{Nu}$ måtte jeg sande det her.

Hurraråbene døde hen. Hundredtusinde blikke, der lyste med den store forventnings glans, rettedes mod triumfbuen ved grænsen. Eresvagten præsenterede gevær, men bajonetterne rystede af bevægelse. Underlig lydeligt klang endnu et næsten grådkvalt udbrud et sted ude i mængden:

»Der er han! - åh, der er han!«

Så blev der stille som i en kirke.

Stemningen var så fortættet - så knugende, at den føltes som en legemlig smerte. Det var, som om alle hjerter stod stille i vældig forventning.

Og se! nu dukker en rytter frem i triumfbuen - på den hvide hest.

Forunderlig ensom, skønt omringet af tusinder - barhovedet og iført infanteriets beskedne, grå uniform - rider kongen langsomt frem, og hans ansigt lyser af den store højtid, skønt de skarpe træk er prægede af den stærkeste sindsbevægelse, og skønt tårer løber ned ad hans kinder, medens blikket vendes opad -.

Det var Danmarks drot og Danmarks søn, som i et af de største øjeblikke, historien har skænket os, græder af glæde; - og havde kong Christian ikke grædt, så havde kongens øjne vel også været de eneste, der var tørre.

Lykkelig den, som fik lov at være med!11

\section{NOTER}

1. Redaktionen takker sognepræst ved Koge Kirke, Jan Basie, for manuskriptet.

2. Knud Gjørups far, Poul Holst Gjørup (1833-1909) var dansk officer. Deltog som premierløjtnant i 1864-krigen og blev såret $\mathrm{i}$ slaget ved Sankelmark den 6. februar 1864 . Sluttede sin officerskarriere som oberst og slotsforvalter på Kronborg 1885-1904.

3. Attentatet på den østrig-ungarske tronfølger Franz Ferdinand den 28. 
juni 1914 i Sarajevo ses normalt som startskuddet på 1 . Verdenskrig.

4. Gjørup hentyder her formentlig til den belgiske politiker Émile Vandervelde (1866-1938). Han var blandt andet belgisk justitsminister $\mathrm{i}$ årene 1918-1921.

5. Jens Christian Hostrup (1818-1892), dansk forfatter og præst. Har skrevet flere dramatiske værker, blandt andet studenterkomedier, samt lyrik og erindringer.

6. Det var den danske gesandt i Paris, H.A. Bernhoft, og ikke Christian X, der underskrev traktaten om Slesvig $i$ Paris den 5. juli 1920. Gjørup tænker her på loven om de sønderjyske landsdeles indlemmelse i Kongeriget, der blev underskrevet af Christian X $\mathrm{i}$ Kabenhavn den 9. juli 1920.

7. Omen accipio, (latin), jeg modtager varslet, dvs. anerkender det som gyldigt for mig.

8. Det er usikkert, hvem Gjørup her hentyder til, men det kan formentlig kun være Axel Vedel (1859-1937), der på det tidspunkt var amtmand over Prestø Amt og medlem af den internationale domstol i Haag.

9. H.D. Kloppenborg-Skrumsager (1868-1930) dansk politiker og gårdejer i Københoved i Sønderiylland. En af danskhedens fremtrædende skikkelser, som 1908-1918 sad i landdagen i Berlin. Efter Genforeningen i 1920 blev han medlem af Landstinget for Venstre. Han støttede oprindelig H.P. Hanssens linje i grænsedragningen, men svingede i 1920 over til Flensborg-linjen.

10. Det var telegrafbestyrer Thorvald Thaulow (1842-93), der i 1876 skrev Slesvig, vort elskede, omstridte Land $\mathrm{til}$ et folkemøde på Skamlingsbanken.

11. Som det fremgår af beretningen, deltog Knud Gjørup i begge dages festligheder; han var således også med ved festlighederne på Dybbøl den 11. juli 1920. Manuskriptet slutter med afsnitsoverskrifen $» 7 \lll$, så man må gå ud fra, at han oprindelig ønskede at fortsætte manuskriptet.

\section{Zusammenfassung}

Der Pastor Knud Gjørup (1879-1936) berichtet in diesem Erinnerungsartikel von den Feierlichkeiten der Wiedervereinigung 1920. Kurzfristig entschloss sich Knud Gjørup, zusammen mit einem guten Bekannten zu den Grenzfeierlichkeiten zu fahren. Er schildert die abenteuerliche Reise mit der Fähre von Korsør nach Fyn und mit dem Nachtzug nach Kolding und nach Taps. Dort erlebte Knud Gjørup den Ritt König Christians X über die alte Grenze hinein nach Sønderjylland - ein bewegender Moment und ein Wendepunkt der dänischen Geschichte, der hier den Lesern als Augenzeugenbericht dargelegt wird. 